\title{
New Natural Product from Botryosphaeria australis, an Endophyte from Mangrove Avicennia marina
}

\section{Produk Alami Baru dari Botryosphaeria australis, Jamur Endopit dari Tumbuhan Mangrove Avicennia marina}

\author{
Robert A. Bara ${ }^{1,3^{*}}$, Ilka Zerfaß1', Daowan Lai', Weihan Lin², Abdessamad Debbab', \\ Heike Brötz-Oesterelt ${ }^{1}$, and Peter Proksch'1. \\ ${ }^{1}$ Institut für Pharmazeutische Biologie und Biotechnologie Heinrich-Heine-Universität Düsseldorf Universitätsstr, \\ Geb.26.23. D-40225 Düsseldorf, Germany \\ ${ }^{2}$ National Research Laboratories of Natural and Biomimetic Drugs, Peking University, Health Science Center, \\ 100083 Beijing, People's Republic of China \\ ${ }^{3}$ Faculty of Fisheries and Marine Science, Sam Ratulangi University, Kampus Unsrat, Bahu Manado 95115, Indonesia \\ *Correspondence Author: robertbara@yahoo.com \\ Article history: \\ Received: 7 March 2013; Revised: 28 Oktober 2013; Accepted: 29 Oktober 2013
}

\begin{abstract}
Chemical investigation of the endophytic fungus Botryosphaeria australis isolated from Avicennia marina originally from Hainan Province, P.R. China, yielded a new compound botryosphaenin (1), from the class of napthoquinone, together with 5 known compounds, botryosterpene (2) and 5-hydroxy-2,7-dimethoxynaphthalene-1,4-dione (3) and its derivatives, 6ethyl-5-hydroxy-2,7-dimethoxynaphthalene-1,4-dione (4), O-methylaspmenone (5), Omethylasparvenone (6) and 5-(carboxymethyl)-7-hydroxy-1,4a-dimethyl-6-methylene decahydron aphthalene-1-carboxylic acid (7). Their structures were determined on the basis of spectroscopic methods including 1D $\left({ }^{1} \mathrm{H},{ }^{13} \mathrm{C}\right.$, and DEPT) and 2D (COSY, HMQC, HMBC, and ROESY) NMR experiments and by mass spectroscopic measurements The new compounds, 1 showed activity against the bacterial pathogens Staphylococcus aureus, several Streptococcus species and Bacillus subtilis, but also against the eukaryotic cell lines THP-1 (human leukemia monocyte) and BALB/3T3 (mouse embryonic fibroblast).
\end{abstract}

Keywords: Mangrove, Avicennia marina, Botryosphaeria australis, antibiotic activities, cytotoxicity

\begin{abstract}
ABSTRAK
Telah dilakukan penelitian kimiawi tentang jamur endofit Botryosphaeria australis yang diisolasi dari bakau Avicennia marina yang tumbuh di kawasan Provinsi Hainan, Republik Rakyat China. Dari penelitian ini diperoleh senyawa botryosphaenin (1), yang merupakan senyawa baru, dari kelas napthoquinone, bersama dengan lima senyawa yang diketahui sebelumnya yaitu, botryosterpene (2) dan 5 - hidroksi - 2,7 - dimetoksinaftalen - 1,4 - dion (3) dan turunannya , 6 - etil - 5 - hidroksi - 2,7 - dimetoksinaftalen - 1,4 - dion (4) , O - metilaspmenon (5) , O - metilasparvenon (6) dan 5 - ( karboksimetil ) - 7 - hidroksi - 1, asam 4a - dimetil - 6 - 1 - metilendekahidronaftalen karboksilat (7). Strukturnya kimia dari senyawa-senyawa tersebut di atas ditentukan berdasarkan analisis spektroskopi Resonansi Magnetik Inti (NMR) termasuk 1D (1H , 13C, dan DEPT) dan 2D ( COSY, HMQC, HMBC, and ROESY) serta menggunakan spektroskopi massa. Senyawa baru yang diisolasi (1) tidak hanya menunjukkan aktivitas yang kuat melawan bakteri patogen Staphylococcus aureus, beberapa spesies Streptococcus dan Bacillus subtilis, tetapi juga terhadap galur sel eukariotik THP - 1 (human leukemia monocyte) dan BALB/3T3 (mouse embryonic fibroblast) .
\end{abstract}

Kata Kunci: Mangrove, Avicennia marina, Botryosphaeria australis, antibiotic activities, cytotoxicity

Permalink/DOI: http://dx.doi.org/10.15578/squalen.v8i3.86

\section{Introduction}

Microorganisms have long served mankind by desirable quality of numerous enzymes and secondary metabolites they generate. Furthermore, only a relatively small number of microbes are used directly in industrial applications (e.g. cheese, beer and wine production) as well as biological control of 
pathogens and have direct usefulness to the human society. This terminology refers to either the microbes themselves or to one or more of their natural products of them.

The term of endophytes mean organisms that reside with plant. They can serve as symbiont either mutuality, commensalics or parasitics to the plant itself. The demand for chemical defense appears to be the basis for endophytic association between plant and their particular endosymbiont (Carroll ,1988; Clay, 1988). They serve as potential sources of novel natural products for exploitation in medicine, agriculture, as well as in industrial sectors (Strobel \& Daisy, 2003). The ability to produce a large number of secondary metabolites by endophytes is mainly related to the filamentous actinomycetes, myxobacteria, Pseudomonas and cyanobacteria in bacteria, and mainly to the filamentous fungi for the eukaryotes (Donadio et al., 2002). Nowaday, this terminology is not only limited to microorganism with living together with higher plant, but also in-between algae and bacteria or fungi or other microorganisms that reside in them. Several of these compounds show pronounced pharmacological activities and are interesting candidates for new drugs primarily in the area of cancer treatment and antibiotics. A number of natural products from the plant or marine organisms show prominent structural similarities to known metabolites of microbial origin, suggesting that microorganisms are at least involved in their biosynthesis of these metabolites or host-symbiont modification.

The needs for new medicines for relieving human from many deadly diseases are never end. Many new developed medicines become less potent to the resistant to the diseases. A developed resistance bacteria, viruses, and other pathogenic microorganisms makes this problem arise exponentially these few years back.

Genus Botryosphaeria is found in many climate environments around the world. Ranging from terrestrial into marine environment, make them able to produce many interesting compounds which have various bioactivities. This genus has been reported as epiphytic fungus on mangrove Sonneratia apetalla (Xu et al., 2011), as an endophyte from cacao (Theobroma cacao L.) (Rubini et al., 2005) as well as an endosymbiont in sponge Tetra auratium (Wiese et al., 2011). The examples of isolated metabolites include Primin(Pongcharoen et al., 2007), 4hydroxymellein (Venkatasubbaiah et al., 1991), and Lasiodiploin (Yang et al., 2006).

In this present study we focused on the discovery of structurally new and biologically active natural products from endophytic fungus, Botryosphaeria australis, was isolated from the leaves of the Avicennia marina collected from Hainan Province, P.R. China, and resulted in the isolation and structural elucidation of one new compouns from the class of polyketide.

\section{Material and Methods}

General. UV spectra were determined on a Dionex instrument with Chromeleon V6.3 as standard software programs. 1D and 2D NMR spectra were obtained at 300 and $500 \mathrm{MHz}$ for ${ }^{1} \mathrm{H}$ and ${ }^{13} \mathrm{C}$, on a DRX-300 and $\mathrm{DRX}-500$ Bruker in mixture of deuterated $\mathrm{CF}_{3} \mathrm{CD}_{2} \mathrm{OD} /$ $\mathrm{D}_{2} \mathrm{O}(1: 1)$ solvent with TMS as an internal standard. Mass spectra were recorded using a LCMS HP1100 Agilent Finnigan LCQDecaXP Thermoquest. HRMS (ESI) spectra were obtained with a FTHRMS-Orbitrap (Thermo-Finnigan) mass spectrometer. Column chromatography both vaccum and pressurised were performed with Silica gel 60M (230-3400 mesh ASTM, Macherey-Nagel GmbH \& Co.KG, Düren, Germany) and Sephadex column was performed using Sephadex LH-20 (Sigma). TLC was carried out with precoated Silica gel plates (TLC silica gel 60 F-254, Merck KGaA, Darmstadt, Germany). Semi preparative HPLC was carried out with Merck Hitachi L-7100 and L-7400 for pump and UV detector respectively, using C-18 column (Dr. Ing H. Knauler, GmbH, Berlin Germany).

Material. The part of Avicennia marina plant was collected from coastal region of Hainan Province P.R. China at the middle of July 2011. The endophytic fungus was isolated from the healthy leaves of related plant by using procedure previously described (Debbab et al. 2009). A strain (strain designation is AMCL7) is kept in of the author's laboratory (P.P). Sequence data have been submitted to GenBank with accession number JQ974951.1.

Identification of Fungal Cultures. Fungal cultures were identified according to a molecular biological protocol by DNA amplification and sequencing of the ITS region as described previously (Wang et al., 2006). The BLAST search result showed that the sequence had $100 \%$ similarity to the sequence of Botryosphaeria australis (FJ037758.1), which is known as well as Neofusicoccum australe.

Cell Proliferation Assay. Cytotoxicity against the human leukemic monocyte cell line THP-1 and the embryonic fibroblast cell line BALB/3T3 was measured using a fluorometric Alamar Blue assay. BALB/3T3 THP1 cells were grown in DMEM medium (PAN Biotech $\mathrm{GmbH}$ ), containing $4.5 \mathrm{~g} / \mathrm{l}$ glucose and $3.7 \mathrm{~g} /$ I $\mathrm{NaHCO}_{3}$, supplemented with $10 \%$ fetal calf serum (v/v), $1 \%$ sodium pyruvate and $1 \%$ L-glutamine. THP1 cells were cultured in RPMI-1640 medium (PAN 
Biotech $\mathrm{GmbH}$ ) containing $2.0 \mathrm{~g} / \mathrm{l} \mathrm{NaHCO}_{3}$, supplemented with $10 \%$ fetal calf serum $(\mathrm{v} / \mathrm{v}), 1 \% \mathrm{~L}-$ glutamine and $1 \%$ penicillin-streptomycin $(10000 \mathrm{U} /$ $\mathrm{ml}$ penicillin and $10 \mathrm{mg} / \mathrm{ml}$ streptomycin; PAN Biotech $\mathrm{GmbH}$ ). Cells were seeded in 96-well plates at $10^{4}$ cells/well in $190 \mu$ l of cell culture medium without penicillin-streptomycin. Test compounds were dissolved in DMSO at a concentration of $10 \mathrm{mg} / \mathrm{ml}$ and twofold serial dilutions were prepared in cell culture medium. $10 \mu \mathrm{l} \mathrm{sample} \mathrm{of} \mathrm{each} \mathrm{compound} \mathrm{dilution} \mathrm{was}$ added to the cells, resulting in final concentration of $0.016-32 \mu \mathrm{g} / \mathrm{ml}$ test compound in 0.00016 to 0.32 $\%$ DMSO. Cell culture medium and cycloheximide (Applichem) served as negative and positive controls, respectively. Plates were incubated for $48 \mathrm{~h}$ at $5 \%$ $\mathrm{CO}_{2}$ and $37^{\circ} \mathrm{C}$. Then, $10 \mu \mathrm{l}$ Alamar Blue/well (Invitrogen) were added and the incubation continued for another $24 \mathrm{~h}$. After $72 \mathrm{~h}$ of total incubation time in the presence of test compounds, fluorescence was read using a 96-well fluorometer (Tecan, infinite M200) with excitation at $560 \mathrm{~nm}$ and emission at $600 \mathrm{~nm}$. Relative fluorescence units (RFU) were determined by the ratio of fluorescence emitted by treated cells vs. untreated cells and served for determination of the $50 \%$ inhibitory concentrations $\left(\mathrm{IC}_{50}\right)$. Experiments were carried out in duplicates.

Antibacterial activity: The Minimal Inhibitory Concentration (MIC) for each bacterial strain was determined by the broth microdilution method according to the recommendations of the Clinical and Laboratory Standards Institute (CLSI and M7-A8 2008). For preparation of the inoculum the direct colony suspension method was used and the final inoculum contained $2-5 \times 10^{5} \mathrm{Cfu} / \mathrm{ml}$. The strain panel included antibiotic-susceptible CLSI quality control strains (Staphylococcus aureus ATCC 29213, Streptococcus pneumoniae ATCC 49619, Escherichia coli ATCC 25922, Klebsiella pneumoniae ATCC 27799, a standard laboratory strain (Bacillus subtilis 168 (Burkholder and Giles 1947), a high-level quinoloneresistant laboratory mutant (Escherichia coli WT-3-1
MB2, Peter Heisig, University of Hamburg, Germany) and the following (multi)drug-resistant clinical isolates: Staphylococcus aureus Mu50 (Hiramatsu et al. 1997), Staphylococcus aureus 25697 (AiCuris, Wuppertal, Germany), Streptococcus agalactiae 013761 and Streptococcus pyogenes 014327 (Hans-Georg Sahl, University of Bonn, Germany), Enterococcus faecalis UW 2689 (Wolfgang Witte, Robert Koch Institute, Wernigerode, Germany), Enterococcus faecium 6011 (Klare et al., 1995) and Pseudomonas aeruginosa B 63230 (Henrichfreise et al. 2005).

\section{Results and Discussion}

The ethyl acetate extract of Botryosphaeria australis were subjected into column chromatography over $\mathrm{LH}-20$ sephadex column eluted using $\mathrm{DCM} / \mathrm{MeOH}$ (1:1) continued by $100 \% \mathrm{MeOH}$ as running eluents thus subjected into semipreparative HPLC to afford a new compounds from polyketide named as botryosphaenin (1) and 5 known compounds, botryosterpene (2) and 5-hydroxy-2,7-dimethoxyna phthalene-1,4-dione, (3) and its derivatives, 6-ethyl-5hydroxy-2,7-dimethoxy naphthalene-1,4-dione (4), Omethylaspmenone (5), O-methylasparvenone (6) and 5-(carboxymethyl)-7-hydroxy-1,4a-dimethyl-6methylen edecahydrona phthalene-14-carboxylic acid (7).

Compound 1 was obtained as a yellow amorphous powder. The UV spectrum showed absorbance at $I_{\max }$ 218, 262, 308 and $430 \mathrm{~nm}$. The molecular formula was determined as $\mathrm{C}_{15} \mathrm{H}_{16} \mathrm{O}_{6}$ on the basis of prominent signal detected at $\mathrm{m} / \mathrm{z} 293.1024[\mathrm{M}+\mathrm{H}]^{+} ; 315.0833$ $[\mathrm{M}+\mathrm{Na}]^{+} ; 607.1773[2 \mathrm{M}+\mathrm{Na}]$ in the HRESIMS. The ${ }^{13} \mathrm{C}$ NMR data of 1 exhibited fifteen carbon signals corresponding to four methyls whereas three of them were methoxy, three methine groups and eight quaternary $\mathrm{C}$-atoms whereas five of them O-bearing carbons, including two $\mathrm{C}=\mathrm{O}$ groups at $d$ at 180.5 (C1) and 191.7 (C-4) on the basis on DEPT spectrum (Table 1). Analysis of ${ }^{1} \mathrm{H}$ NMR spectrum indicated the

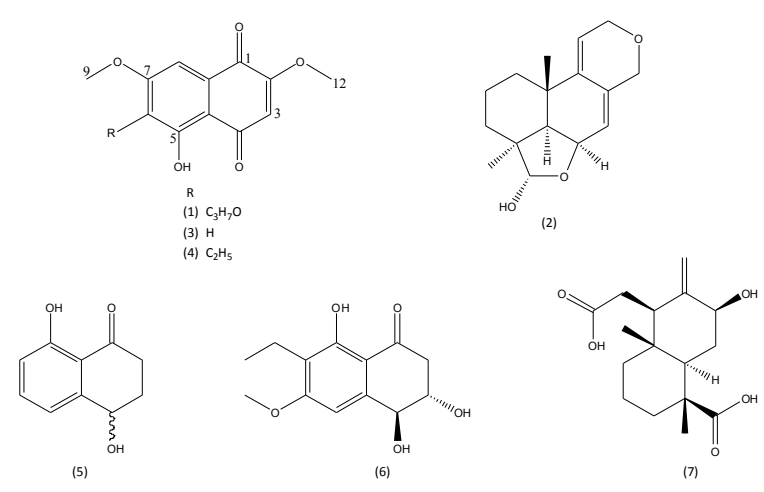

Figure 1. Isolated compounds of $B$. australis. 
Table $1 .{ }^{13} \mathrm{C}$ and ${ }^{1} \mathrm{H}$ NMR data of 1 . Recorded at $300 \mathrm{MHz}$ in $\mathrm{CD}_{3} \mathrm{OD}$; $d$ in ppm; $\mathrm{J}$ in $\mathrm{Hz}$

\begin{tabular}{ccl}
\hline Position & $\delta^{13} \mathbf{C}$ & \multicolumn{1}{c}{$\boldsymbol{\delta}^{1} \mathbf{H}(\boldsymbol{J}$ in $\mathrm{Hz})$} \\
\hline 1 & 180.5 & \\
2 & 162.3 & \\
3 & 110.4 & $6.18(1 \mathrm{H} ; \mathrm{s})$ \\
4 & 191.7 & \\
5 & 162.3 & \\
6 & 123.6 & \\
7 & 164.8 & \\
8 & 103.6 & $7.29(1 \mathrm{H} ; \mathrm{s})$ \\
9 & 133.3 & \\
10 & 110 & \\
11 & 72.1 & $5.12(1 \mathrm{H} ; \mathrm{q} ; J=6.7 ; 6.7 ;$ \\
12 & 19.2 & $1.56(3 \mathrm{H} ; \mathrm{d} ; J=6.7)$ \\
13 & 56.8 & $3.99(3 \mathrm{H} ; \mathrm{s})$ \\
14 & 57.3 & $3.92(3 \mathrm{H} ; \mathrm{s})$ \\
15 & 56.9 & $3.23(3 \mathrm{H} ; \mathrm{s})$ \\
\hline
\end{tabular}

presence of one methyl which resonating at $d^{H} 1.56$ $(3 \mathrm{H} ; \mathrm{d} ; \mathrm{J}=6.7 ; \mathrm{H}-12)$ and three methoxy resonating at $d^{\mathrm{H}} 3.23(3 \mathrm{H} ; \mathrm{s} ; \mathrm{H}-15), d^{\mathrm{H}}$ at $3.92(3 \mathrm{H} ; \mathrm{s} ; \mathrm{H}-14)$ and $d^{\mathrm{H}}$ at $3.99(3 \mathrm{H} ; \mathrm{s} ; \mathrm{H}-13)$, three methine groups divided as one O-bearing methane resonating at $d^{\mathrm{H}} 5.12(1 \mathrm{H}$; q; $J=6.7 ; \mathrm{H}-11)$ and two aromatic methine protons resonating at $d^{\mathrm{H}} 6.18(1 \mathrm{H} ; \mathrm{s} ; \mathrm{H}-3)$ and at $d^{\mathrm{H}} 7.29(1 \mathrm{H}$; $\mathrm{s} ; \mathrm{H}-8)$. Analysis of HMBC spectrum showed correlation between $\mathrm{H}-3$ to keto- groups $\mathrm{C}-1$ and $\mathrm{C}-4$ and $\mathrm{C}-2$ and $\mathrm{C}-10$. The aromatic $\mathrm{H}-8$ correlates to $\mathrm{C}$ 1, C-6, C-7, C-9 and C-10. Thus, proton bound to oxygenated carbon $\mathrm{C}-11$ correlates to $\mathrm{C}-5, \mathrm{C}-7$, methyl $\mathrm{C}-12$ and methoxy $\mathrm{C}-15$. Proton $\mathrm{H}-12$ correlates to C-6 and C-11 Figure 2).

Cross peaks were observed from methoxy protons to their adjacent carbon $\mathrm{C}-13, \mathrm{C}-14$ and $\mathrm{C}-15$. Both olefinic protons $\mathrm{H}-3$ and $\mathrm{H}-8$ correlate to keto- group
C-1. In fact, COSY data confirmed direct correlation of $\mathrm{H}-11$ and $\mathrm{H}-12$ and also long range correlations of $\mathrm{H}-3$ and $\mathrm{H}-14$ and $\mathrm{H}-8$ and $\mathrm{H}-13$. Therefore, from the data above, the structure of compound 1 was determined as 5-hydroxy-2,7-dimethoxy-6-(1methoxyethyl) naphthalene-1,4-dione, named botryosphaenin. The NMR data were slight similar as reported in literature (Poch et al. 1992), except the additional aliphatic methoxy $(\mathrm{H}-15)$.

Botryosphaenin (= 5-hydroxy-2,7-dimethoxy-6-(1methoxyethyl)naphthalene-1,4-dione, 2), yellow amorphous. UV maxima at $I_{\max } 218 ; 262 ; 308 ; 430$ nm. [á]D20 +29.5 (c 0.02, acetone). El-MS $=277$ (loosing $\mathrm{CH}_{3}$ ) and 292. HRESIMS $\mathrm{m} / \mathrm{z} 293.1024$ $[\mathrm{M}+\mathrm{H}]^{+} ; 315.0833[\mathrm{M}+\mathrm{Na}]^{+} ; 607.1773[2 \mathrm{M}+\mathrm{Na}]$ (calcd for $\left.\mathrm{C}_{15} \mathrm{H}_{17} \mathrm{O}_{6}, 293.1025 ; \mathrm{C}_{15} \mathrm{H}_{16} \mathrm{O}_{6} \mathrm{Na}, 315.0833\right) .{ }^{1} \mathrm{H}$ and ${ }^{13} \mathrm{C}$ : see table 1.

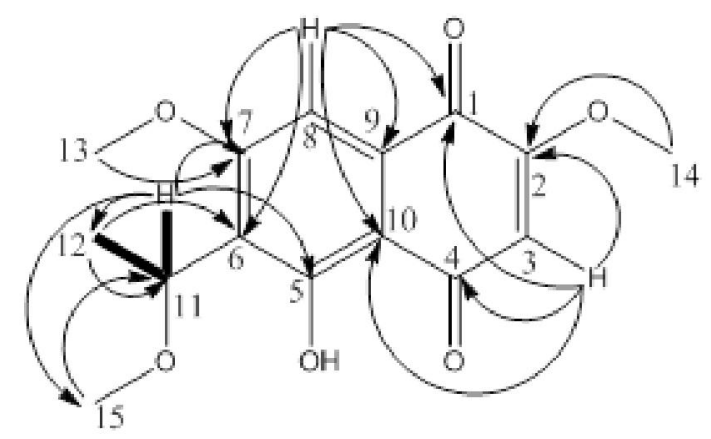

Figure 2. Structure of 1 , and selected $\mathrm{HMBC}$ (arrows) and $\mathrm{HH}-\mathrm{COSY}$ correlations (bold lines). 


\subsection{Antibacterial activity}

The new compounds 1 and the known compounds 3-7 were evaluated for their antibacterial activity against a diverse spectrum of bacterial species, including antibiotic-susceptible reference strains and multiresistant clinical isolates (Table 2). Among these, only compound $\mathbf{1}$ and its close congener $\mathbf{4}$ displayed antibacterial activity, similar in strength and spectrum. Both compounds inhibited the growth of Gram-positive bacteria of the genera Staphylococcus, Streptococcus and Bacillus with minimal inhibitory concentrations in the range of 2 to $32 \mu \mathrm{g} / \mathrm{ml}$ and affected even highlevel (multi)drug-resistant clinical isolates like $S$. aureus Mu50, S. aureus 25697, S. agalactiae 013761 and S. pyogenes 014327. In preceding studies on the basis of diverging strain panels and agar dilution as the predominate method for MIC determination, a lack of antibacterial activity had been observed for compound 2, 3, 4, 6 and 7 (Gerber and Wieclawek 1966; Otomo et al. 1983; Yuan et al. 2009; Xu et al. 2011), while compound 5 had been active against $B$. subtilis at an elevated concentration of $100 \mu \mathrm{g} / \mathrm{ml}$ (Kokubun et al. 2003).

\subsection{Cytotoxicity}

Compounds 1-7 were further tested for their cytotoxic activity against THP-1 human leukemic monocyte cells and BALB/3T3 mouse embryonic fibroblast cells (Table 3). The $\mathrm{IC}_{50}$ values of compound 1 for both cell lines were in the range of $0.5-2 \mu \mathrm{g} / \mathrm{ml}$, indicating that compound 1 lacks specificity for prokaryotes. Again, compound $\mathbf{4}$ displayed a similar

Table 2. Minimal inhibitory concentration $[\mu \mathrm{g} / \mathrm{ml}]$ of compound 1-7 MIC values were determined by the broth microdilution method in Mueller-Hinton broth according to the rec ommendations of the Clinical Laboratory Standards Institute

\begin{tabular}{|c|c|c|c|c|c|c|c|c|}
\hline Tested organism & Resistance phenotype ${ }^{a}$ & \multicolumn{7}{|c|}{ Compound } \\
\hline Gram-positive & & 1 & 2 & 3 & 4 & 5 & 6 & 7 \\
\hline $\begin{array}{l}\text { Staphylococcus aureus } \\
\text { ATCC } 29213\end{array}$ & susceptible & 8 & $>64$ & $>64$ & 16 & $>64$ & $>64$ & $(32)^{b}$ \\
\hline $\begin{array}{l}\text { Staphylococcus aureus } \\
\text { Mu50 }\end{array}$ & $\begin{array}{l}\mathrm{CAZ}^{\mathrm{Rc}}, \mathrm{CLA}^{\mathrm{R}}, \mathrm{CIP}^{\mathrm{R}}, \mathrm{CLI}^{\mathrm{R}}, \mathrm{DOX}^{\mathrm{R}}, \\
\mathrm{ERY}^{\mathrm{R}}, \mathrm{MET}^{\mathrm{R}}, \mathrm{MXF}^{\mathrm{R}}, \mathrm{KAN}^{\mathrm{R}}, \\
\mathrm{TEL}^{\mathrm{R}}, \mathrm{RIF}^{\mathrm{R}},\left(\mathrm{MRSA}^{\mathrm{d}}, \mathrm{VISA}^{\mathrm{e}},\right)\end{array}$ & 16 & $>64$ & $>64$ & 8 & $>64$ & $>64$ & $>64$ \\
\hline $\begin{array}{l}\text { Staphylococcus aureus } \\
25697\end{array}$ & $\begin{array}{l}A M X^{R}, \mathrm{CHL}^{\mathrm{R}}, \mathrm{CIP}^{\mathrm{R}}, \mathrm{CLI}^{\mathrm{R}}, \mathrm{ERY}^{\mathrm{R}}, \\
\text { FOS }^{\mathrm{R}}, \mathrm{GEN}^{\mathrm{R}}, \mathrm{KAN}^{\mathrm{R}}, \\
\mathrm{NIT}^{\mathrm{R}}, \mathrm{TET}^{\mathrm{R}} \text { (MRSA) }\end{array}$ & 8 & $>64$ & -64 & $8(4)$ & $>64$ & $>64$ & 64 \\
\hline $\begin{array}{l}\text { Streptococcus pneumoniae } \\
\text { ATCC } 49619\end{array}$ & susceptible & 2 & $>64$ & 32 & 2 & 64 & 64 & 32 \\
\hline $\begin{array}{l}\text { Streptococcus agalactiae } \\
013761\end{array}$ & DOX & 32 & $>64$ & $>64$ & 32 & $>64$ & $>64$ & $>64$ \\
\hline $\begin{array}{l}\text { Streptococcus pyogenes } \\
014327\end{array}$ & DOX' & 16 & $>64$ & 32 & 8 & $>64$ & $>64$ & 64 \\
\hline $\begin{array}{l}\text { Enterococcus faecalis UW } \\
2689\end{array}$ & $\begin{array}{l}\mathrm{CLA}^{\mathrm{R}}, \mathrm{ERY}^{\mathrm{R}}, \mathrm{MXF}^{\mathrm{R}}, \mathrm{TEL}^{\mathrm{R}}, \\
\left(\mathrm{VRE}^{\mathrm{g}}\right)\end{array}$ & $>64$ & $>64$ & $>64$ & $>64$ & $>64$ & $>64$ & $>64$ \\
\hline Enterococcus faecium 6011 & $E R Y^{R}, \operatorname{CLA}^{R}, T^{R} L^{R}(V R E)$ & $>64$ & $>64$ & $>64$ & $>64$ & $>64$ & $>64$ & $>64$ \\
\hline Bacillus subtilis 168 & susceptible & 32 & $>64$ & 64 & $4(2)$ & $>64$ & $>64$ & -64 \\
\hline $\begin{array}{l}\text { Gram-negative } \\
\text { Pseudomonas aeruginosa B } \\
63230\end{array}$ & $\begin{array}{l}\mathrm{CAZ}^{\mathrm{R}}, \mathrm{CIP}^{\mathrm{R}}, \mathrm{CPM}^{\mathrm{R}}, \mathrm{GEN}^{\mathrm{R}}, \mathrm{IMI}^{\mathrm{R}}, \\
\mathrm{MER}^{\mathrm{R}}, \mathrm{PIP} / \mathrm{TAZ} \mathrm{Z}^{\mathrm{R}}\end{array}$ & $>64$ & $>64$ & $>64$ & $>64$ & $>64$ & $>64$ & $>64$ \\
\hline $\begin{array}{l}\text { Escherichia coli ATCC } \\
25922\end{array}$ & susceptible & $>64$ & $>64$ & $>64$ & $>64$ & $>64$ & $>64$ & $>64$ \\
\hline Escherichia coli WT-3-1 MB2 & $\mathrm{CIP}^{\mathrm{R}}$ & $>64$ & $>64$ & $>64$ & $>64$ & $>64$ & $>64$ & $>64$ \\
\hline $\begin{array}{l}\text { Kleb siella pneumoniae } \\
\text { ATCC } 27799\end{array}$ & $\mathrm{DOX}^{\mathrm{R}}, \mathrm{KAN}^{\mathrm{R}}$ & $>64$ & $>64$ & $>64$ & $>64$ & $>64$ & $>64$ & $>64$ \\
\hline
\end{tabular}


Table 3. $I C_{50}$ values $[\mu \mathrm{g} / \mathrm{ml}$ ] of compound 1-7 in THP-1 human leukemic monocyte and BALB/3T3 mouse embryonic fibroblast cells. $\mathrm{IC}_{50}$ values were determined using a fluorometric Alamar Blue assay

\begin{tabular}{lccccccc}
\hline \multirow{2}{*}{ Tested cell line } & \multicolumn{7}{c}{ Compound } \\
\cline { 2 - 8 } & $\mathbf{1}$ & $\mathbf{2}$ & $\mathbf{3}$ & $\mathbf{4}$ & $\mathbf{5}$ & $\mathbf{6}$ & $\mathbf{7}$ \\
\hline THP-1 & 0.5 & 3 & 7 & 3 & $>32$ & $>32$ & 15 \\
BALB/3T3 & 2 & $>32$ & $>32$ & 10 & $>32$ & $>32$ & $>32$ \\
\hline
\end{tabular}

result. Compound 2 and $\mathbf{3}$ inhibited only THP-1, but not the generally more robust BALB cells and compounds 5-7 demonstrated no cytotoxicity against the cell lines tested.

\section{Conclusion}

The new compounds (1) shows strong antibacterial activity toward several bacteria including multi drugs resistant clinical isolate $S$. aureus Mu50. However, it was also shows strong activity against cell lines tested, indicating its lack specificity to prokaryotes and eukaryotes cells.

\section{Acknowledgment}

Heike Goldbach-Gecke is gratefully acknowledged for performing the cytotoxicity assays. This study was supported by grants of the state North RhineWestphalia and the European Union (European Regional Development Fund, Investing in your future) to I.Z. and H.B-O.; DAAD scholarship to R. A. B., as well as BMBF fund to P.P and D.L

\section{References}

Burkholder, P. R., \& Giles, N. H., Jr. (1947). Induced biochemical mutations in Bacillus subtilis. $A m \mathrm{~J}$ Bot. 34(6): 345-8.

Carroll, G. (1988). Fungal endophytes in stems and leaves: from latent pathogen to mutualistic symbiont. Ecology. 69 (1): 2-9.

Clay, K. (1988). Fungal endophytes of grasses: a defensive mutualism between plants and fungi. Ecology. 69 (1): 10-16.

CLSI \& M7-A8. (2008). Methods for Dilution Antimicrobial Susceptibility Tests for Bacteria That Grow Aerobically. Approved Standard. Clinical and Laboratory Standards Institute (CLSI)

CLSI, M. A. (2008). Methods for dilution antimicrobial susceptibility tests for bacteria that grow aerobically. Approved standard. Clinical and Laboratory Standards Institute.

Debbab, A., Aly, A. H., Edrada-Ebel, R., Wray, V., Müller, W. E. G., Totzke, F., Zirrgiebel, U., Schälchtele, C., Kubbutat, M. H. G., Lin, W. H., Mosaddak, M., Hakiki, A., Proksch, P. \& Ebel, R. (2009). Bioactive metabolites from the endophytic fungus Stemphylium globuliferum isolated from Mentha pulegium. Journal of Natural Products, 72(4), 626-631.

Donadio, S., Monciardini, P., Alduina, R., Mazza, P., Chiocchini, C., Cavaletti, L., Sosio, M. \& Puglia, A. M. (2002). Microbial technologies for the discovery of novel bioactive metabolites. Journal of Biotechnology, 99(3), 187-198.

Gerber, N. N. \& Wieclawek, B. (1966). The Structures of Two Naphthoquinone Pigments from an Actinomycete1. The Journal of Organic Chemistry, 31(5), 1496-1498.

Henrichfreise, B., Wiegand, I., Sherwood, K. J., \& Wiedemann, B. (2005). Detection of VIM-2 metallobeta-lactamase in Pseudomonas aeruginosa from Germany. Antimicrob Agents Chemother, 49(4), 16689.

Hiramatsu, K., Hanaki, H., Ino, T., Yabuta, K., Oguri, T. \& Tenover, F. C. (1997). Methicillin-resistant Staphylococcus aureus clinical strain with reduced vancomycin susceptibility. J. Antimicrob Chemother, 40(1), 135-6.

Klare, I., Heier, H., Claus, H., Bohme, G., Marin, S., Seltmann, G., Hakenbeck, R., Antanassova, V. \& Witte, W. (1995). Enterococcus faecium strains with vanAmediated high-level glycopeptide resistance isolated from animal foodstuffs and fecal samples of humans in the community. Microb. Drug Resist., 1(3), 265-72.

Kokubun, T., Veitch, N. C., Bridge, P. D. \& Simmonds, M. S. J. (2003). Dihydroisocoumarins and a tetralone from Cytospora eucalypticola. Phytochemistry, 62(5), 779-782.

Otomo, N., Sato, H., \& Sakamura, S. Novel phytotoxins (1983). produced by the causal fungus of the shoot blight of larches. Agricultural and biological chemistry, 47(5), 1115-1119.

Poch, G. K., Gloer, J. B. \& Shearer, C. A. (1992). New bioactive metabolites from a freshwater isolate of the fungus Kirschsteiniothelia sp. J. Nat. Prod., 55(8), 1093-1099.

Pongcharoen, W., Rukachaisirikul, V., Phongpaichit, S. \& Sakayaroj, J. (2007). A new dihydrobenzofuran derivative from the endophytic fungus Botryosphaeria mamane PSU-M76. Chem. Pharm. Bull. (Tokyo), 55(9), 1404-1405.

Rubini, M. R., Silva-Ribeiro, R. T., Pomella, A. W., Maki, C. S., Araujo, W. L., Dos Santos, D. R. \& Azevedo, J. L. (2005). Diversity of endophytic fungal community of 
cacao (Theobroma cacao L.) and biological control of Crinipellis perniciosa, causal agent of Witches' Broom Disease. Int. J. Biol. Sci., 1(1), 24-33.

Strobel, G. \& Daisy, B. (2003). Bioprospecting for microbial endophytes and their natural products. Microbiol. Mol. Biol. Rev., 67(4), 491-502.

Venkatasubbaiah, P., Sutton, T. B., \& Chilton, W. S. (1991). Effect of phytotoxins produced by Botryosphaeria obtusa, the cause of black rot of apple fruit and frogeye leaf spot. The American Phytopathological Society, 81(3), 243-247.

Wang, S., Li, X.-M., Teuscher, F., Li, Diesel, A., Ebel, R., Proksch, P. \& Wang, B.-G. (2006). Chaetopyranin, a benzaldehyde derivative, and other related metabolites from Chaetomium globosum, an endophytic fungus derived from the marine red alga Polysiphonia urceolata. Journal of Natural Products, 69(11), 1622-1625.
Wiese, J., Ohlendorf, B., Biamel, M., Schmaljohann, R. \& Imhoff, J. F. (2011). Phylogenetic Identification of Fungi Isolated from the Marine Sponge Tethya aurantium and Identification of Their Secondary Metabolites. Marine Drugs, 9(4), 561-585.

Xu, Y. H., Lu, C. H., Zheng, Z. H. \& Shen, Y. M. (2011). New Polyketides Isolated from Botryosphaeria australis Strain ZJ12-1A. Helvetica Chimica Acta, 94(5), 897902.

Yang, R. Y., Li, C. Y., Lin, Y. C., Peng, G. T., She, Z. G., \& Zhou, S. N. (2006). Lactones from a brown alga endophytic fungus (No. ZZF36) from the South China Sea and their antimicrobial activities. Bioorganic and Medicinal Chemistry Letters, 16(16), 4205-4208.

Yuan, L., Zhao, P. J., Ma, J., Lu, C. H., \& Shen, Y. M. (2009). Labdane and Tetranorlabdane Diterpenoids from Botryosphaeria sp. MHF, an Endophytic fungus of Maytenus hookeri. Helvetica Chimica Acta, 92(6), 1118-1125. 